\title{
Ukraine Depressive National Economy Destructive Factors
}

\author{
Liana Ptashchenko, \\ Department of Finance and Banking \\ Poltava National Technical Yuri \\ Kondratyuk University \\ Poltava, Ukraine \\ lianaptaschenko63@meta.ua \\ http://orcid.org/0000-0002-4228-0421 \\ Valeriia Volkova, \\ Department of Finance and Banking \\ Vasyl Stus Donetsk National University \\ Vinnytsia, Ukraine \\ valeriya.volkova.donetsk@gmail.com \\ http://orcid.org/0000-0003-1539-6194
}

\author{
Alina Glushko, \\ Department of Finance and Banking \\ Poltava National Technical Yuri \\ Kondratyuk University \\ Poltava, Ukraine \\ glushk.alina@gmail.com \\ http://orcid.org/0000-0002-4086-1513
}

\author{
Nelia Volkova, \\ Department of Finance and Banking \\ Vasyl Stus Donetsk National University \\ Vinnytsia, Ukraine \\ nelia.volkova.donetsk@gmail.com \\ http://orcid.org/0000-0003-3790-3636
}

\begin{abstract}
It is proved that in economics depression is characterized not only as a lasting, long-term decline in industries economic activity but as a consequence of destructive factors influence. Those factors that are primary cause of the national economy depressed state in the context of importance of issues related to Ukraine economic development are investigated. These factors include big business merger with politics, hidden economy, corruption and high level of money laundering. It is defined that consequences of these factors influence include increase in country's debt dependence, labor migration, low rates of economic growth, etc. Author's definition of "depressed economy" notion is suggested. A pyramid of destructive factors and their consequences influencing the nation economy depressiveness is built up. The pyramid has the form of an inverted one, since it demonstrates more clearly the author's concept, which emphasizes the primary cause of all problems in the national economy, which is merging of state and business economic interests. An opinion of the necessity of forming a public administration paradigm based on the principles of integrity, patriotism and state economic interests priority over personal and business interests is expressed.
\end{abstract}

Keywords - national economy, depressed economy, corruption, national debt, economic interests, business, authority, hidden economy, destructive factors.

\section{INTRODUCTION}

Ukraine's national economy underwent transformational processes as well as economies of other countries in Eastern and Central Europe. Thus, in contrast to those countries that have successfully overcome all the negative effects of economic convergence and are developing as equal partners in the European economic space, economic system of Ukraine is object-oriented and incapable of competing in individual international markets since demonstrates signs of depression. The thesis is confirmed by economic situation in Ukraine and destructive factors that hamper the national economy development. The main of these factors include the following:

- threats to economic independence caused by the country's debt dependence;

- unfavorable investment climate in production sector;
- industrial and regional disproportions in economic development;

- lagging of manufacturing sector from the consumption one as well as from financial services market;

- instability and investment ineffectiveness of financial organizations caused by NBU nonstrategic policy;

- considerable energy consumption and fuel and energy dependence;

- high level of corruption and hidden economy ;

- merger of big business and politics and as a result lobbying interests of a few oligarchs over national economic interests;

- stratification of society and total destruction of middle class;

- criminalization of relations between state institutions and business, distribution of Ukraine economy sectors between clans.

Considering the noted problems actuality, the aim of the article is study of the factors influencing the national economy depressiveness, analysis of depressed economy characteristics and and defining priority grounds for creation Ukraine's national economy new paradigm of management.

\section{MAIN MATERIAL}

General law of the market type economy is its development cyclical nature: from rise to recession, followed by stagnation in production and business life (depression), after which reactivation and recovery in the economy are observed. Scientists prove that market economy cyclical nature is caused by objective factors. Material basis of cyclical nature is fixed capital physical renewal, although the direct stimulus for the crisis may include a variety of reasons, and above all, it is financial turmoil. The essence of economic development is evident in abrupt transitions from one stationary state to another on a qualitatively different level [1]. However, if most countries of the world have survived crisis and are developing successfully, there is an 
objective need to analyze the primary causes that hinder the development of Ukraine national economy and constrain the country's recovery from depression.

In economics, depression is described as a sustained, long-term decline in industries economic activity. This is a more serious economic downturn than a slowdown in economic activity during usual business cycle.

Depressions are characterized by rise in unemployment, limited availability of investment resources (often due to some form of banking or financial crisis), declining volumes of production, threats of government debt defaults, substantially reducing trade (especially international trade) and currency volatility.

In other words, depression is a state of economics, which is the result of a long period of negative economic activity, and decline in GDP. It is often described as a more severe form of recession, which results in increase in unemployment, a jump in credit default. Reductions in income and production, currency devaluation and deflationary economics [2].

Issues of Ukraine's territories depressiveness and directions of their development state regulation are considered in the numerous scientists' works. Thus, M. Baranovskyi studies institutional methods of depressed territories economic and social development [3]; M. Vachovych considers measures by which he suggests evaluating economic state of depressed territories development from the point of financial security view, which provides assessment of depressed region integrated development level, fiscal and investment support of this development [4], and together with M. Kupyra offers a generalized interpretation of "depressive territories" by modern domestic and foreign scientists-economists, creates requirements to define the concept and features of depressed regions [5]. Based on regional policy of countries with developed market economy experience, scientists $\mathrm{O}$. Amosha and I. Petenko suggest directions of Ukraine's domestic old industrial regions policy [6], while $\mathrm{V}$. Khalimon focuses attention on overcoming rural territories depressive state [7]. $\mathrm{V}$. Melnychuk proposes methodology for financial capacity assessing by economy institutional sectors (general state management, financial corporations, households, non-profit organizations) [8].

However, scientists' interest in solving problems of depressed territories has gradually decreased in recent years, and studies on economy depressiveness are lacking. The researchers do not review such notion as "depressive economics". This characteristics is more often used when speaking about a certain territory, like "depressed region", "depressed town" etc.

Appealing to historical experience, we can note that "depressed territory" concept was first applied in 1929 during the Great Economic Crisis in Great Britain [9]. The regions (regions) with the highest unemployment rate were considered to be depressed, and state regulation measures were determined as priorities for ensuring economic development in such regions.

In the context of importance of issues concerning the economic development of Ukraine, recovery of the national economy from depressed state, we will analyze the factors having direct impact on this state.

The most influential of these factors include underground economics, merger of big business with politics, corruption and a high level of money laundering.

Let us note that according to research conducted by Austrian Kepler University Professor Friedrich Schneider, the size of hidden economy in Europe made up 18\% of GDP. The lowest share of hidden economy in GDP is traditionally observed in Switzerland (6.5\%), Austria (8.2\%), Luxembourg (8.3\%), the Netherlands (9\%) and Great Britain $(9.4 \%)$. In Germany the indicator is estimated at $12.2 \%$ from GDP [9]. In Ukraine, these indicators of hidden economy are considerably higher. Beginning from the period of economy transformation (Fig. 1).

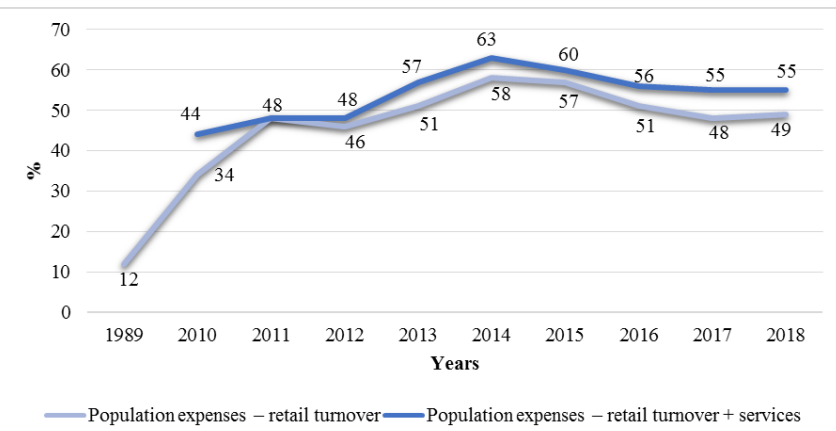

Fig. 1. The level of hidden economy according to the current and improved version of the "population expenditures - retail turnover" method, $\%$ of GDP official volume

Source: calculations by the Ministry of Economic Development and Trade [10].

It should be considered that the "population expenditures - retail turnover" method reveals the highest hidden economy level compared to such methods as monetary and electric ones, as well as method of enterprises loss-making and, in our opinion, more accurately characterizes indicators of hidden economy real level.

Experts in the Economic Forum on Hidden Economy in Ukraine named the main ways of "growing" the hidden economy in Ukraine (Fig. 2).

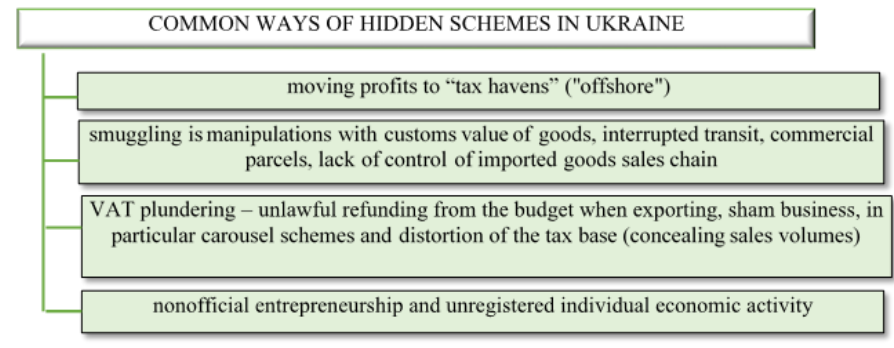

Fig. 2. Main methods of hidden schemes in Ukraine

Figures expressed by experts at the Forum are impressive in their size: the amount of offshore schemes is equal to 260320 billion UAH per year, budget losses from them - 50-65 billion UAH per year, the amount of hidden part in violation of customs rules and smuggling - 80-230 billion UAH per 
year, and budget losses make up 25-70 billion UAH [11]. Upon that, state losses from unofficial employment and employers' payments of the major part of the salary in the "converted" form are not released to public.

In any national economy, there are three main groups of entities, namely the state, business and households, or private individuals. Each of these subjects has its own economic interests, which as a rule do not coincide and are the cause of a conflict. In case a businessperson becomes a public officer, but does not leave his business, he is tempted to use his official position or state leverage (if the position is rather high) in the interests of personal or group enrichment. The conflict of interest is laid here from the very beginning. However, Ukrainian peculiarity is no conflict of interest, because, as practice shows, contradictions between state interests and business are always resolved in favor of the latter [12]. A situation, in which government officers do not give up business (that is a merger of big business and politics), is typical for Ukraine and, as we are deeply convinced, is the primary cause of all other destructive factors that have been affecting depression of the national economy for almost three decades. This fact is so obvious that almost everyone is talking about it, but almost nothing is done so far.

One of the negative consequences of the phenomenon described above is almost unpunished dirty money laundering. Though measures in the area of prevention and counteraction to legalization (laundering) of income from crime, terrorist financing and financing of weapons of mass destruction distribution, which are defined in the legislative acts of Ukraine [13], as well as reports on the implementation of these measures can be positively assessed, however actual facts concerning the situation with dirty money laundering, hidden economy and corruption, testify about very little progress in this direction.

Another important factor influencing depressive state of the national economy is corruption.

According to the results of the World Corruption Perception Index in 2018, Ukraine scored 32 points out of a hundred possible, and ranked 122th, sharing it with Mali, Malawi and Liberia.

Ranking principles suggest that the highest-ranking score have states with the minimal corruption; the lowest have the most corrupted countries. Still, only those states, which according to World Corruption Perception Index score 61 and more, are considered to be relatively satisfactory. This "Club of countries with low corruption" is headed by Denmark (88 points) while the last places in it belong to Botswana and Israel (61 points each). Less corrupted than Ukraine are all EU countries including Bulgaria, which has the worst indices in the European Union - 42 points [14].

The index is based on several independent surveys involving international financial and human rights experts, including from the Asian and African Development Banks, the World Bank and the Freedom House international organization.

Here's how Ukraine's rating indices over the past three years look like as viewed by various international organizations (Table 1).
Table 1 shows that not all international organizations note decrease in corruption level in Ukraine, like integral index testifies.

TABLE I. DYNAMICS OF CORRUPTION FACILITATING INDICATOR
RATING INDICES IN UKRAINE ON THE BASIS OF INTERNATIONAL ORGANIZATIONS RESEARCH*

\begin{tabular}{|c|c|c|c|c|c|c|c|c|c|}
\hline \multirow[b]{2}{*}{ 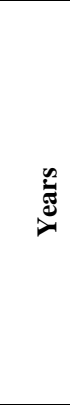 } & \multicolumn{9}{|c|}{$\begin{array}{c}\text { Ranking indices on the basis of international } \\
\text { organizations research }\end{array}$} \\
\hline & 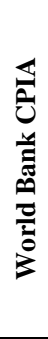 & 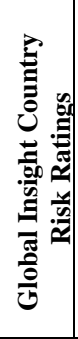 & 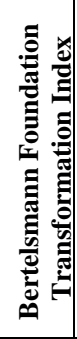 & 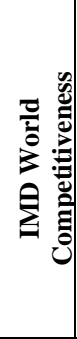 & 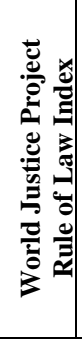 & 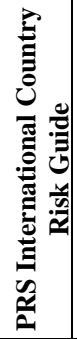 & 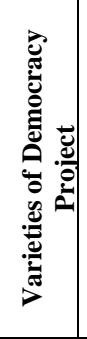 & 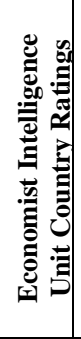 & 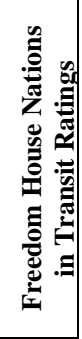 \\
\hline 2016 & 29 & 34 & 36 & 29 & 32 & 24 & 23 & 19 & 33 \\
\hline 2017 & 30 & 22 & 41 & 26 & 36 & 32 & 30 & 20 & 36 \\
\hline 2018 & 32 & 35 & 41 & 29 & 36 & 32 & 22 & 20 & 36 \\
\hline
\end{tabular}

In particular, Economist Intelligence Unit Country Ratings, PRS International Country Risk Guide, Bertelsmann Foundation Transformation Index and Freedom House Nations in Transit Ratings consider corruption in Ukraine unchangeable, while Varieties of Democracy Project estimates 8 points increase in corruption in 2018 as compared to 2017 and 1 point higher than 2016 level.

According to the Corruption Facilitation Index, countries with 100 to 050 score are considered to be less corrupted than more corrupted ones with 049 to 000 index. The lower the value of the index, the more corrupted the country is considered to be.

Research proved that Ukraine both during a period of economy transformation and now remains quite a corrupted country. Corruption dynamics index proves this (Fig.3).

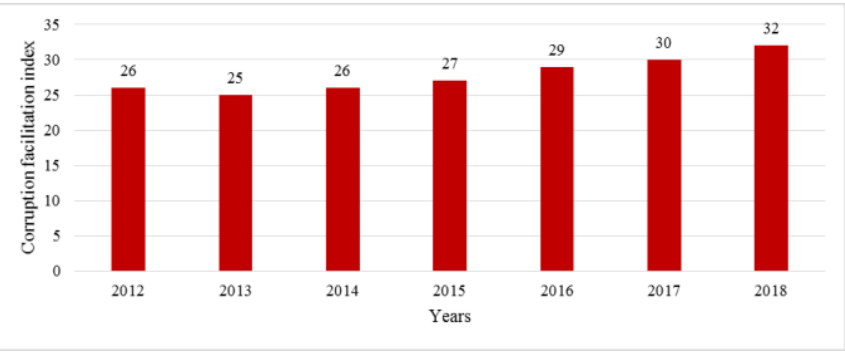

Fig. 3. Corruption dynamics index in Ukraine

Source: built up on the materials [16]

Until 2011 the index scored from 0 (the highest corruption level) to 10 (no corruption), where Ukraine occupied 134th position and was in the middle level of corrupted countries (Fig.4).

Thus, the fact that there are no changes in the issues of fight against corruption in the country is doubtless.

Besides the destructive factors described above, there exist real hazards that also influence the national economy depressive condition. 


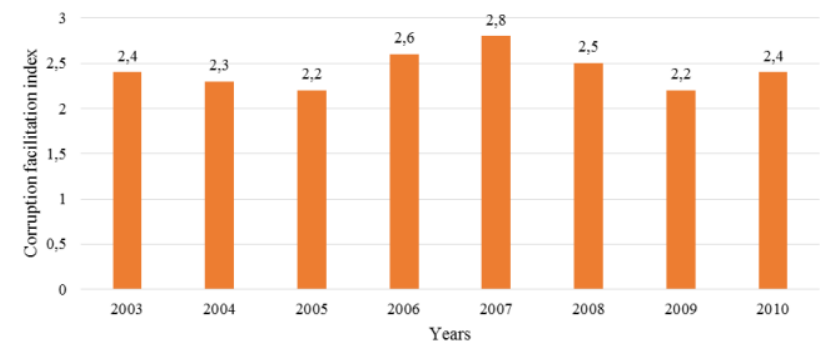

Fig. 4. Corruption facilitation index dynamics according to the old scale until 2011

One of the most serious threats to this is debt security. Ukraine's debt dependence is growing at a high pace, while industrial sector is not developing, and GDP growth is on average insignificant. 2).

The following statistic data are given to prove this (Table

TABLE II. UKRAINE’S NATIONAL DEBT STRUCTURE AND DYNAMICS

\begin{tabular}{|c|c|c|c|c|c|c|c|}
\hline \multirow[b]{2}{*}{$\underset{\nu}{\Xi}$} & \multicolumn{7}{|c|}{ Index } \\
\hline & 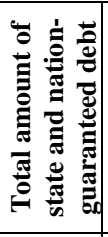 & 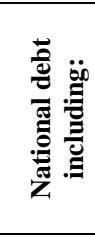 & 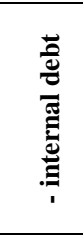 & 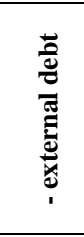 & 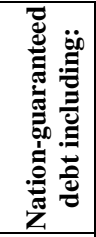 & 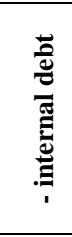 & 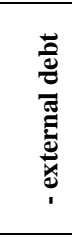 \\
\hline 2010 & 432.24 & 323.48 & 141.66 & 181.81 & 108.76 & 13.83 & 94.93 \\
\hline 2011 & 473.12 & 357.27 & 161.47 & 195.81 & 115.85 & 12.24 & 103.61 \\
\hline 2012 & 515.51 & 399.22 & 190.3 & 208.92 & 116.29 & 16.21 & 100.08 \\
\hline 2013 & 549.46 & 453.35 & 246.04 & 207.31 & 96.11 & 23.2 & 72.92 \\
\hline 2014 & 1037.9 & 888.64 & 414.09 & 474.55 & 149.25 & 28.69 & 120.56 \\
\hline 2015 & 1571.77 & 1333.9 & 508 & 825.9 & 237.9 & 21.5 & 216.4 \\
\hline 2016 & 1929.76 & 1650.83 & 670.65 & 980.19 & 278.93 & 19.08 & 259.84 \\
\hline 2017 & 2141,67 & 1833.71 & 753.4 & 1080.3 & 307.96 & 13.28 & 294.69 \\
\hline 2018 & 2168.63 & 1860.5 & 761.09 & 1099.4 & 308.13 & 10.32 & 297.81 \\
\hline
\end{tabular}

*Built up on the materials [17]

Thus, Ukraine's national debt has a negative tendency towards growing. Since this index itself does not characterize the corresponding threats presence, it is necessary to carry out comparative analysis of Ukraine's national debt and GDP (Table 3).

TABLE III. UKRAINE'S NATIONAL DEBT AND GDP (NOMINAL) DYNAMICS FROM 2010 TO 2018 (IN BILLION UAH)

\begin{tabular}{|l|l|l|l|l|}
\hline Year & $\begin{array}{c}\text { National } \\
\text { debt }\end{array}$ & $\begin{array}{c}\text { GDP } \\
\text { (nominal) }\end{array}$ & $\begin{array}{c}\text { Correlation } \\
\text { (national } \\
\text { debt / GDP) }\end{array}$ & $\begin{array}{c}\text { Inflation } \\
\text { index, \% }\end{array}$ \\
\hline 2010 & 432.4 & 1082.57 & 39.9 & 109.1 \\
\hline 2011 & 473.12 & 1316.6 & 35.9 & 104.6 \\
\hline 2012 & 515.51 & 1408.89 & 36.6 & 99.8 \\
\hline 2013 & 549.46 & 1454.93 & 37.8 & 100.5 \\
\hline 2014 & 1037.9 & 1566.73 & 66.2 & 124.9 \\
\hline 2015 & 1571.77 & 1979.46 & 79.4 & 143.3 \\
\hline 2016 & 1929.76 & 2383.18 & 81.0 & 112.4 \\
\hline 2017 & 2141.67 & 2982.92 & 71.8 & 113.7 \\
\hline 2018 & 2168.63 & 3558.7 & 60.9 & 109.8 \\
\hline
\end{tabular}

From the table it becomes obvious that there was five times increase in Ukraine's national debt for 8 years, while nominal GDP increased 3,3 times and real one - 2,86 times. Let us analyze the situation with external debt in its correlation to Ukraine's real GDP (Table 4).

TABLE IV. UKRAINE'S NATIONAL DEBT AND GDP (NOMINAL) DYNAMICS FROM 2010 TO 2018 ((IN BILLION UAH)

\begin{tabular}{|l|l|l|l|l|}
\hline Year & $\begin{array}{c}\text { National } \\
\text { debt }\end{array}$ & $\begin{array}{c}\text { GDP } \\
\text { (real) }\end{array}$ & $\begin{array}{c}\text { Correlation } \\
\text { (national } \\
\text { debt / GDP) }\end{array}$ & \multicolumn{1}{|c|}{$\begin{array}{c}\text { Inflation } \\
\text { index, \% }\end{array}$} \\
\hline 2010 & 432.24 & 1079.35 & 40.0 & 109.1 \\
\hline 2011 & 473.12 & 1138.34 & 41.56 & 104.6 \\
\hline 2012 & 515.51 & 1141.06 & 45.18 & 99.8 \\
\hline 2013 & 549.46 & 1140.75 & 48.17 & 100.5 \\
\hline 2014 & 1037.9 & 1062.84 & 97.65 & 124.9 \\
\hline 2015 & 1571.77 & 1430.29 & 109.89 & 143.3 \\
\hline 2016 & 1929.76 & 2304.430 & 83.74 & 112.4 \\
\hline 2017 & 2141.67 & 2445.587 & 87.57 & 113.7 \\
\hline 2018 & 2168.63 & 3083.409 & 70.33 & 109.8 \\
\hline
\end{tabular}

A problem of external borrowings is currently of great importance for Ukraine. In terms of efficient use, the resources involved can become a positive factor of economic growth [19]. Under continuation of the trend, social tension in Ukrainian society is intensifying, while economic depression is deepening. There are other numerous threats to Ukraine's national economy, which influence destructively the economy real sector, financial markets and social state in the country.

Researchers calculated that during the years of its existence the Hryvnia have devaluated 16 times, while consumer prices have risen 15 times, and industrial prices 27 times. More than half of the banks disappeared from the financial market of Ukraine after 2013. The NBU estimated losses from banks bankruptcy at $38 \%$ of GDP [20]. Declared by the government economic growth of $3.3 \%$ in 2018 remains lower than the world one $(3.7 \%)$.

Depressive state of the national economy, insufficient social policy of the government has led to the outflow of active labor force abroad. According to the Ministry of Social Policy, 3 million 200 thousand Ukrainian citizens are abroad on a permanent basis. From seven to nine million people on average take part in this "mobile migration process" annually. The Ministry of Foreign Affairs stated about 1 million of Ukrainian citizens leaving the country every year for permanent or temporary employment [21].

Ukraine is under constant IMF control since it has received financial support for a total of 10.2 SDRs (SDRs special drawing rights) over the past 5 years, almost as much as in previous 19 years (SDR 10.7 billion).

The IMF does not have enough time to monitor the existing stabilization programs, namely Stand-by (2014), EFF (2015), Stand-by (2018), when the NBU announces the need for the next stabilization program. According to the deputy director of the Institute of Economics and Forecasting of the National Academy of Sciences of Ukraine, Doctor of Economic Sciences Sergii Korablin, it is not surprising that in such a situation, it is time to speak not about the conditions of financial stability of Ukraine, but about the 
reasons for its absence [20]. Research enabled authors to conclude that the most influential destructive factor Ukraine's depressed economy is merging of business and the state and creation of new formations, namely state officialsbusinessmen, who make business economic interests the priority over the state economic interests. This generates a number of other destructive factors that exist or arise from the primary ones. It is advisable to build a pyramid of depressed economy factors.

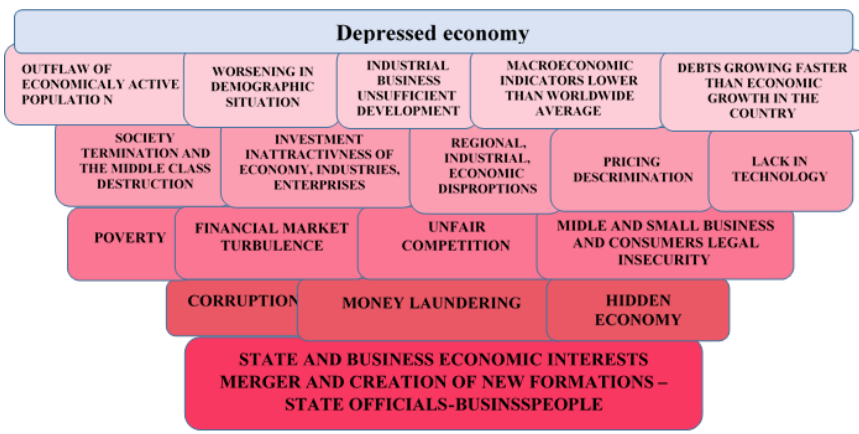

Fig. 5. Destructive factors pyramid and their consequences influencing the national economy depressiveness (built up by authors)

The pyramid has inverted form, since it demonstrates the author's concept more clearly, where emphasizes the primary cause of all the national economy problems as merging of state and business economic interests. The mentioned merging seems so tight that is requires either radical intervention or changes in the public consciousness, and accordingly, a paradigm of state governance on the principles of integrity, patriotism, the priority of state economic interests over personal and business interests. Only than the national economy will recover from depression, start working and become competitive, and Ukraine will be a subject, not objects of relations in the international economic space.

\section{CONCLUSIONS}

Conducted research enabled authors to reveal their own vision of reasons constraining the national economy of Ukraine development, making it non-competitive and depressed. Scientific novelty is in authors' definition of depressive economy depressed economy as such a state of the national economy, under which once developed economy in terms of structure adjustment influence and under pressure from internal destructive factors is undergoing decline, development destabilizing (turbulence of the financial market, industrial sector stagnation, deterioration of social, demographic, infrastructure and environmental components) becomes noncompetitive and objective in international economic relations and is in a state of socio-economic danger. For the first time a hierarchical pyramid of destructive factors and their consequences influencing national economy depressiveness was formed. This enables creating clearer understanding of the problem's importance in the national economy, which restrict its development and affect its destructive condition. The ideas formulated by the authors, might positively influence the change in state management paradigm, which will be created based on integrity, patriotism, priority of state economic interests over personal and business interests.

\section{REFERENCES}

[1] I.B. Shkodina, and H.Ia.Yurkiv, "Global economy cyclical development in terms of financial instability". Financial and crediting activity: theory and practice issues, Collection of scientific papers, Kharkiv: Khibs UBC NBU, vol. 1 (10), pp.318 - 323, 2011.

[2] Read more [Electronic resource]. - Access mode: http://www.businessdictionary.com/definition/economicdepression.html. Accessed on: July 10, 2019.

[3] M. Baranovskyi, "Ukraine depressed territories development stimulating mechanisms: institutional aspects", Magazine of social and economic geography, vol. 13(2), pp. 26-30, 2012.

[4] M.I. Vakhovych, Region steady development financial policy: methodology of formation and realization mechanism: monography, Lutsk, Nadstyria, 2007.

[5] I.M. Vakhovych, M.I. Kupyra, "Depressed region economic notion essence justification", Economic sciences. Regional economy Seria. Collection of scientific papers. Lutsk National Technical University, vol. 11 (43), Lutsk: RVV Lutskoho NTU, pp. 27 - 34, 2014.

[6] O. Amosha, "Depressed regions development priorities", NDFI Scientific works, vol. 3 (60), pp. 50 - 56, 2012.

[7] V.L. Khalimon, "Ways of overcoming rural territories depressed condition in AIC regional developmentsystem", AIC Ekonomics, no. 8, pp. $104-110,2012$.

[8] V.H. Melnychuk, "Condition and main tendencies of finances development in Ukraine's economy institutional sectors", Ukraine's Finances, no. 9, pp. 104-116, 2006.

[9] J. Kitchin, Cycles and Trends in Economic Factors [Online]. Available: https://www.jstor.org/stable/1927031. Accessed on: July 12, 2019.

[10] F. Schneider, "Shadow Economy in Turkey and in other OECDCountries: What do we (not) know?", University of Linz, Austria, pp. 15-18, 2012.

[11] Hidden economy tendencies in Ukraine, Department of economic strategy and macroeconomic prognostics [Online]. Available: www.me.gov.ua/Documents/List?lang=uk-UA\&id=e384c5a7-6533. Accessed on: July 10, 2019.

[12] Forum against "shadow" in economy [Online]. Available: https://delo.ua/news-companies/dijte-uchasniki-forumu-proti-tini-vekonomici-visunuli-vimogi-336196/ . Accessed on: July 10, 2019.

[13] Losiev Ihor. Business and authority Centauri [Online]. Available: https://tyzhden.ua/Columns/50/184503. Accessed on: July 10, 2019.

[14] On Prevention and Counteraction to Legalization (Laundering) of the Proceeds from Crime, Terrorist Financing and Financing of the Proliferation of Weapons of Mass Destruction. Law of Ukraine, Verchovna Rada vidomosti (VRV), no. 50-51, pp. 20 - 57, 2014.

[15] Index of Corruption Perception: Ukraine has strengthened its position [Online]. Available: https://www.radiosvoboda.org/a/29735869.html. Accessed on: July 12, 2019.

[16] Index of corruption perception in the world [Online]. Available: cpi.ti-ukraine.org/. Accessed on: July 14, 2019

[17] Gross Domestic product [Online]. Available: https://index.minfin.com.ua/ua/economy/gdp/2018/. Accessed on: July 10, 2019

[18] National debt and nation-guaranteed debt [Online]. Available: https://www.minfin.gov.ua/.../derzhavnyi-borh-ta-harantova. Accessed on: July 10, 2019.

[19] A.V. Tomashevska, T.V. Smykovchuk, "The level of GDP of Ukraine: analysis and dynamics of development", Naukovyi visnyk Uzhhorodskoho natsionalnoho universytetu, vol. 3 (20), pp. 104-110, 2018 .

[20] Serhii Korablin, Great depression. Ukraine, Dzerkalo tyzhnia, edition 30, 2015 [Online]. Available: https://dt.ua/macrolevel/velikadepresiya-ukrayina-_html/ Accessed on: July 11, 2019.

[21] Site of Ministry of social policy [Online]. Available: https://hromadske.ua/.../za-kordonom-perebuvayut-32-mln. Accessed on: July $11,2019$. 